\title{
Teaching NeuroImages: \\ Massive abdominal CSFoma
}

Mitchell S.V. Elkind,

MD, MS

Jeffrey Forris Beecham Chick, MD

\section{Figure Imaging}

Nikunj Rashmikant

Chauhan, MD

Katherine Marie Mullen, MD

Nirav Vikram Kamdar, MD

Bharti Khurana, MD

Correspondence to

Dr. Chick:

jchick@partners.org
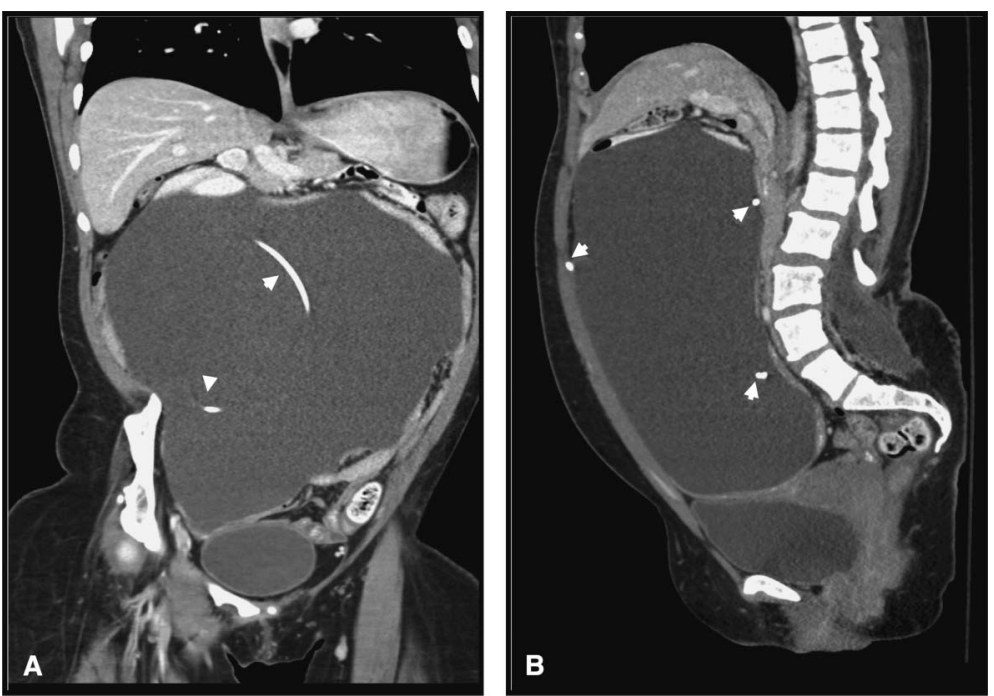

(A) Coronal and (B) sagittal images from CT of the abdomen and pelvis with IV contrast material demonstrating the course of a ventriculoperitoneal shunt catheter with a massive, $25 \times 24 \times 12 \mathrm{~cm}$, loculated, CSFoma, or CSF pseudocyst, surrounding the ventriculoperitoneal shunt catheter (arrowheads).

A 31-year-old woman with congenital hydrocephalus status post ventriculoperitoneal shunt placement 23 years earlier presented with abdominal distention. The patient denied fever, headache, or sensory or motor abnormalities. Examination was notable for a tense abdomen. $\mathrm{CT}$ of the abdomen and pelvis demonstrated a massive, loculated, CSFoma, or CSF pseudocyst (figure). Ventriculoperitoneal shunts are associated with a variety of complications including disruption of the tube, obstruction of the tip, infection, intestinal perforation, tip migration, and CSFoma development. ${ }^{1}$ CSFoma is a rare complication, thought to be caused by low-grade shunt infection, chronic inflammation, increased CSF protein, or peritoneal adhesions, and is estimated to occur in $1.0 \%$ to $4.5 \%$ of cases, with a typical occurrence within 3 weeks to 5 years of shunt placement. ${ }^{2,3}$ Treatment consists of external drainage or surgical excision followed by reconstruction of the shunt system. ${ }^{4}$

\section{AUTHOR CONTRIBUTIONS}

All authors contributed equally to the creation of the text, preparation of the images, and revision of the manuscript.

\section{STUDY FUNDING}

No targeted funding reported.

\section{DISCLOSURE}

The authors report no disclosures relevant to the manuscript. Go to Neurology.org for full disclosures.

\section{REFERENCES}

1. Besson R, Hladky JP, Dhellemmes P, Debeugny P. Peritoneal pseudocyst: ventriculo-peritoneal shunt complications. Eur J Pediatr Surg 1995;5:195-197.

2. Rainov N, Schobess A, Heidecke V, Burkert W. Abdominal CSF pseudocyst in patients with ventriculo-peritoneal shunts: report of fourteen cases and review of the literature. Acta Neurochir 1994;127:73-78.

3. Coley BD, Shiels WE, Elton S, Murakami JW, Hogan MJ. Sonographically guided aspiration of cerebrospinal fluid pseudocysts in children and adolescents. AJR Am J Roentgenol 2004;183:1507-1510.

4. Hahn YS, Engelhard M, McLone DG. Abdominal CSF pseudocyst: clinical features and surgical management. Pediatr Neurosci 1985-1986;12:75-79.

From the Department of Radiology (J.F.B.C., N.R.C., K.M.M., B.K.), Brigham and Women's Hospital, Harvard Medical School; and Department of Anesthesia, Critical Care and Pain Medicine (N.V.K.), Massachusetts General Hospital, Harvard Medical School, Boston, MA. 


\section{Neurology}

\section{Teaching NeuroImages: Massive abdominal CSFoma}

Jeffrey Forris Beecham Chick, Nikunj Rashmikant Chauhan, Katherine Marie Mullen, et al. Neurology 2013;80;e146

DOI 10.1212/WNL.0b013e318289705e

\section{This information is current as of March 25, 2013}

Updated Information \& Services

References

Subspecialty Collections

Permissions \& Licensing

Reprints including high resolution figures, can be found at: http://n.neurology.org/content/80/13/e146.full

This article cites 4 articles, 0 of which you can access for free at: http://n.neurology.org/content/80/13/e146.full\#ref-list-1

This article, along with others on similar topics, appears in the following collection(s):

All Education

http://n.neurology.org/cgi/collection/all_education All Imaging http://n.neurology.org/cgi/collection/all_imaging Clinical neurology examination http://n.neurology.org/cgi/collection/clinical_neurology_examination CT http://n.neurology.org/cgi/collection/ct

Other Education

http://n.neurology.org/cgi/collection/other_education

Information about reproducing this article in parts (figures,tables) or in its entirety can be found online at:

http://www.neurology.org/about/about_the_journal\#permissions

Information about ordering reprints can be found online: http://n.neurology.org/subscribers/advertise

Neurology ${ }^{\circledR}$ is the official journal of the American Academy of Neurology. Published continuously since 1951, it is now a weekly with 48 issues per year. Copyright (C 2013 American Academy of Neurology. All rights reserved. Print ISSN: 0028-3878. Online ISSN: 1526-632X.

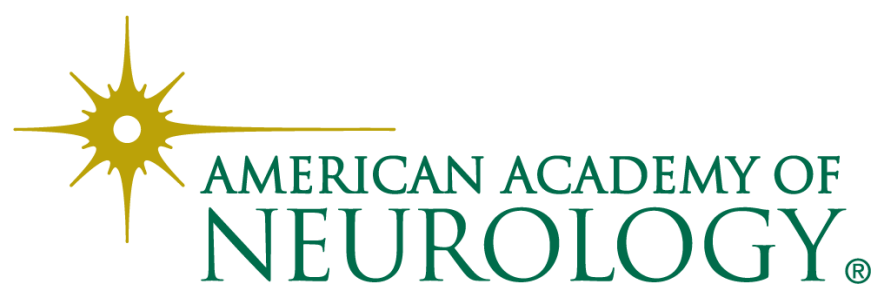

